\title{
Criterion for Maximum Entropy Spectral Analysis of Heart Rate Diurnal Rhythm in a Horse
}

\author{
Yoshiki YAMAYA $^{1}$, Katsuyoshi KUBO ${ }^{2}$, Akio AMADA ${ }^{2}$, and Kei SATO ${ }^{1}$ \\ ${ }^{1}$ Laboratory of Veterinary Surgery, College of Agriculture and Veterinary Medicine, Nihon University, \\ 1866 Kameino, Fujisawa-shi, Kanagawa 252, Japan and ${ }^{2}$ Equine Research Institute, Japan Racing \\ Association, 5-27-7 Tsurumaki, Setagaya-ku, Tokyo 154, Japan
}

(Received 6 May 1993/Accepted 2 August 1993)

\begin{abstract}
The application of the maximum entropy spectral analysis to the chronotropisms of heart rate diurnal rhythm in a horse was examined. As the sampling interval and the order of the autoregressive model (model order) had to be determined before the estimate by maximum entropy method (MEM), these parameters were examined. As the results, 5- or 10-minute interval and $\mathrm{N}$ (the number of data)/2 for the estimate of over a 6 -hour period and $\mathrm{N} / 5$ for that of the 1- to 6-hour period were adequate for the sampling interval and the model order. It was presumed that by the MEM using these parameters, the heart rate diurnal rhythm of this horse had approximately 1-, 4-, 5-, 9-, and 26-hour periods.

Key words: diurnal rhythm, heart rate, horse, maximum entropy method
\end{abstract}

Jpn. J. Equine Sci. 4(1): 73-77, 1993

It is well known that many physiological phenomena such as heart rate, body temperature, breathing, etc. in humans have a period of approximately 24 hours, namely circadian rhythm [9]. In horses, it has been reported that circadian rhythms exist in heart rate, body temperature, corticosteroid production, etc. [3-5, 8, 17]. But most of their reports did not use the statistics method to analyze circadian rhythms. Only Evans estimated the periodicity of the body temperature and heart rate circadian rhythms by the cosiner method [4]. The cosiner analysis is useful to estimate whether the observed data is fitted to the circadian rhythm, namely, the known single period such as the 24-hour period [11].

In biorhythms, there are many types of rhythms according to their lengths or periods, not only circadian rhythms. Therefore, it is necessary to apply the maximum entropy method (MEM) of spectral analysis to estimate many chronotropic components at the same time. Originally, this method has been used for the periodic analysis of diastrophism in the field of geography and recognized as the method in that the resolution property of the power spectrum is considerably superior and the positions of the poles point out accurate frequencies even if the time-series data includes the irregular fluctuations and is a short length [18].

Before induction of MEM, we must examine and determine the criterion for choosing the order of the autoregressive model (model order) that is to be fitted to the time-series data. It is known from experience that too short model order results in a highly smoothed estimate, whereas an excessive one introduces spurious detail into the spectrum [18]. Ostuka et al. have presented the application of MEM to 
analyze the diurnal variations of heart rate and blood pressure in humans [12, 15] and cardiac bradyarrhythmia in rats $[13,14]$. Also Kashiwamura and Shinde have showed the fluctuations in body temperature of a cow consisted of the circadian and the ultradian rhythm of a 120- to 480-minute period with using the maximum entropy spectral analysis [7]. These authors, however, have not presented a method of computing the required model order.

Furthermore, it is known that the sampling interval influences the precision of time-series analysis, that is, the signal-tonoise ratio of the time-series data will be high if the interval is suitable to that data but the actual chronotropisms will be erased if the improper interval is used [2].

In this paper, the sampling interval of heart rate and the required model order for applying the maximum entropy spectral analysis to the heart rate diurnal rhythm of a horse were investigated and the availability of this method was discussed.

Condition. A male Thoroughbred horse of 8 years old was used for this study. The electrocardiograms were recorded continuously for 24 hours with Holter electrocardiograph (Fukuda Denshi, SM-29), which was placed in the bag $(25 \times 50 \mathrm{~cm})$ on his back attached to the saddle girth. The horse was stabled in a standard stall and could move freely in the enclosure during 24 hours. The feeding times were 7:30 and 16:00, and the water was given ad libitum. After recording, the number of $\mathrm{P}$ waves per minute was counted from the electrocardiogram tracings and then three time-series data consisted of 1440, 288 and 144 points with sampling intervals of 1-, 5- and 10-minute were provided (Fig. 1). Three model orders for MEM were chosen as follows: these were the order calculated by the Akaike final prediction error cri-

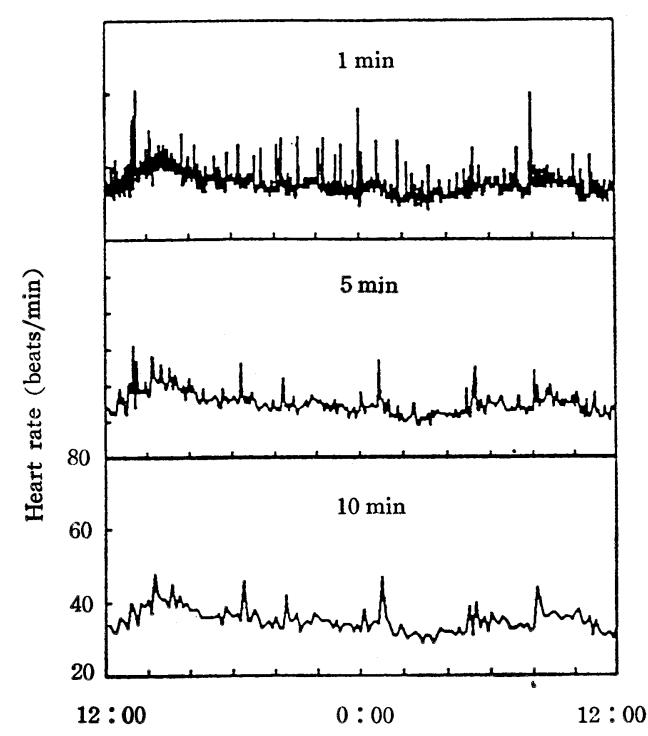

Fig. 1. Three time-series data by sampling interval of 1 minute (upper), 5 minutes (middle), and 10 minutes (lower) in equine heart rate

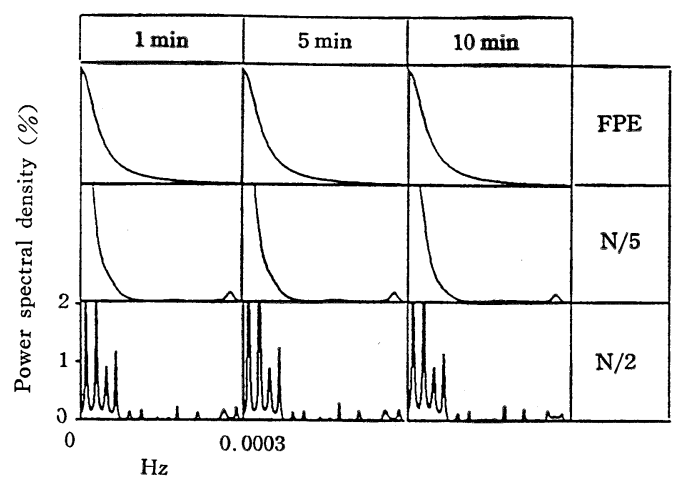

Fig. 2. Power spectra analyzed in Fig. 1 using model orders of FPE, $\mathrm{N} / 5$ and $\mathrm{N} / 2$ (see text for details)

terion (FPE) [1], $\mathrm{N}$ (the number of data) $/ 5$ and $\mathrm{N} / 2$ proposed by Ulrych and Bishop [18]. The maximum entropy spectral analysis was performed by the general purpose computer (NEG, PG-9801VX21) with the soft programmed by BASIC language [2, $10,18]$. The frequency bandwidth of the spectral analysis was 0 to $0.0003 \mathrm{~Hz}$, over an approximately 50-minute period, and the realization of the power spectrum was 300-point.

Analysis and Estimation. The effects of 

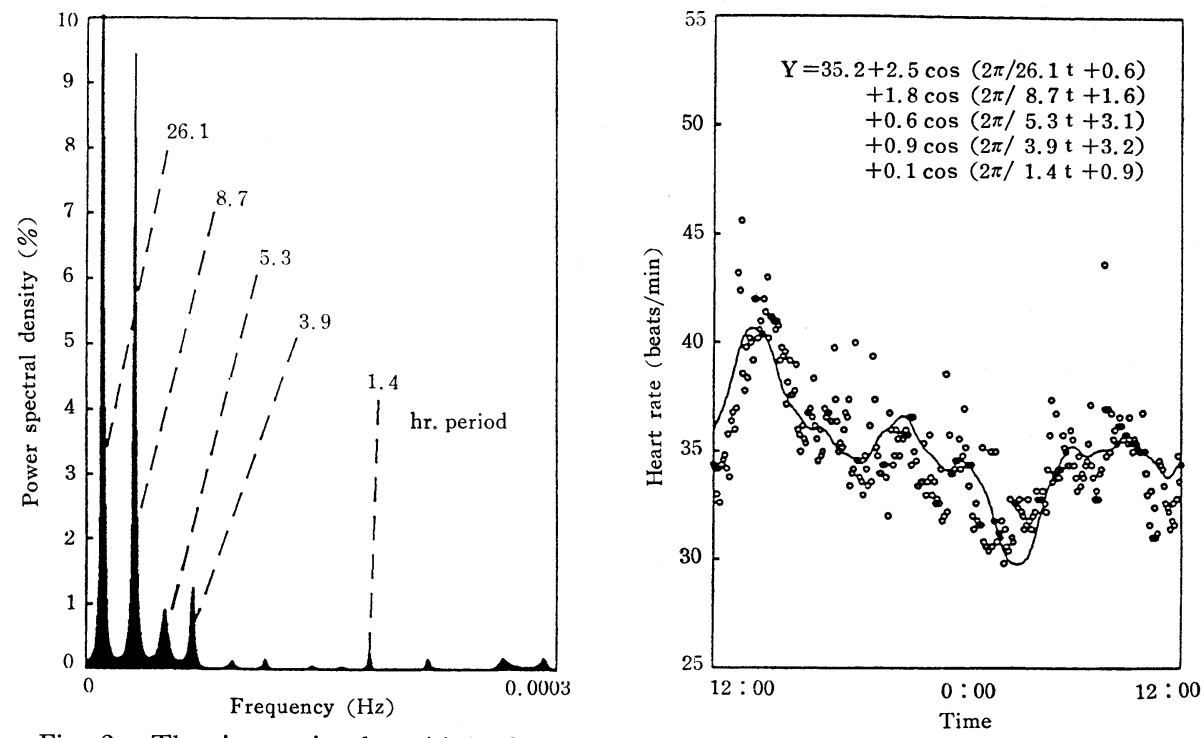

Fig. 3. The time-series data (right figure, dots) in equine heart rate and the calculated curve (right figure, solid line) by the nonlinear least squares method using hour periods of MEM power spectrum (left figure)

The values in left figure show periods of poles. The formula in right figure $\left(\mathrm{Y}=\mathrm{M}+\mathrm{A}_{1} \operatorname{COS}\left(\omega_{1} \mathrm{t}-\phi_{1}\right)+\ldots \mathrm{A}_{\mathrm{n}} \mathrm{COS}\left(\omega_{\mathrm{n}} \mathrm{t}-\phi_{\mathrm{n}}\right)\right.$, $\mathrm{Y}$ : estimate, $\mathrm{M}$ : mesor, A: amplitude, $\omega$ : period, $\mathrm{t}:$ time, $\phi$ : acrophase) illustrates a solid line.

the sampling interval and the model order to the power spectrum of the spectral analysis were examined (Fig. 2). Power spectra of MEM which were estimated with the model order of FPE to three time-series data collected at 1-, 5- and 10-minute intervals, showed the smoothed spectral lines with a pole of the sector type at the low frequency bandwidth. In cases of MEM which were estimated with the model order of $\mathrm{N} / 5$ to three time-series data, power spectra also showed the smoothed spectral lines with two poles at the low and high frequency bandwidths. On the other hand, power spectra of MEM, estimated with the model order of $\mathrm{N} / 2$ to three time-series data, showed the sharp spectral lines with many poles and then 26.1-, 8.7-, 5.3-, 3.9-, and 1.4-hour periods were determined from five poles with high amplitudes. Therefore, whether these periods were fitted to the original time-series data were examined by the nonlinear least squares

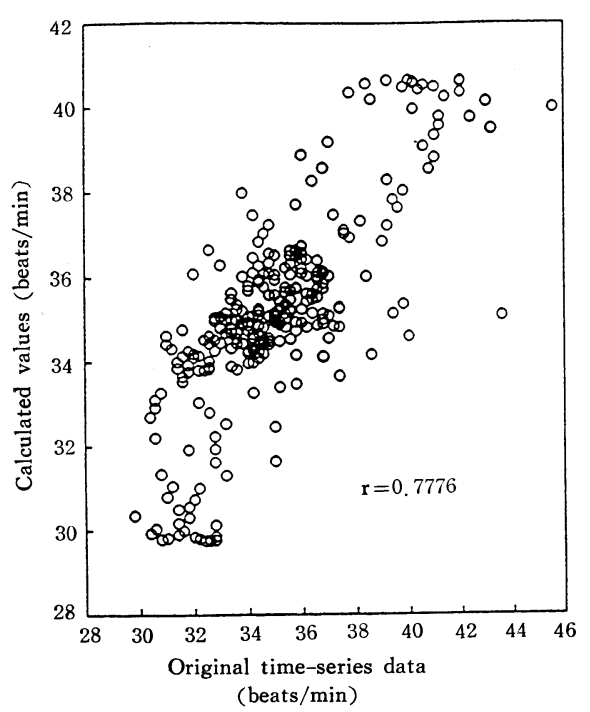

Fig. 4. The relationship between the original timeseries data in equine heart rate and the values from calculated curve by nonlinear least squares method at the same time

This scatter graph is illustrated the significant correlation $(\mathrm{p}<0.01)$.

method. The calculated curve by that method was suited to the original time- 
series data visually and statistically (Figs. 3 and 4). These have suggested that MEM can estimate accurately the equine heart rate diurnal rhythms.

In this study, power spectra had always no differences among three sampling intervals, whereas the model order had a great effect on those as many poles appeared into the power spectrum when the model order was a long length as $N / 2$. However, most of poles with high amplitudes pointed out actual chronotropisms. It was suggested that many significant poles were contained in a pole of the sector type at low frequency bandwidth in estimates with the model orders of FPE and N/5. In addition, we considered that a pole recognized at high frequency bandwidth in estimates with the model order of $\mathrm{N} / 5$ showed the period typified many poles with low amplitudes at the same bandwidth in those with $\mathrm{N} / 2$. Ohtomo has recommended an approximately $\mathrm{N} / 2$ as the model order for the analysis of the blood pressure diurnal rhythm in humans [11]. In the maximum entropy spectral analysis of equine heart rate diurnal rhythm, however, we proposed that it was necessary to determine the model order corresponding to the estimated frequency bandwidth such as: $\mathrm{N} / 2$ for the estimate of the low frequency bandwidth of over the approximately 6-hour period and $\mathrm{N} / 5$ for the high frequency bandwidth of the 1- to 6- hour period were adequate to the model order. We could use any of the timeseries data sampled at 1-, 5- and 10-minute intervals because power spectra did not change by sampling intervals. It was thought that 5- and 10-minute intervals were convenient for the sampling interval as the results of the consideration into disadvantages such as the computation time, time complexity and space complexity.
Furthermore, it was shown that the heart rate diurnal rhythm of a horse examined in this study had approximately 1-, 4-, 5-, 9-, and 26-hour periods. It was thought that a 26-hour period was correspondent to circadian rhythms [9] and a 9-hour period indicated the feeding interval of daytime from 7: 30 to 16: 00, which was a 8.5hour period. Kashiwamura and Shinde [7] have reported that fluctuations in body temperature of a cow had the ultradian rhythm of the 120- to 480-minute periods. In addition, Shimada [16] has found oscillations in mean arterial pressure, heart rate, cardiac output, and total peripheral resistance with periods near 1.5 hours in dogs. Perhaps two 4- and 5-hour periods and a 1-hour period may indicate the heart rate variations that related to the equine body temperature diurnal rhythm and show that the cardiovascular system is controlled cyclically at that period in horses. Thus, the detailed causes of these period will be cleared by the spectral analysis to the periodicities of equine body temperature, blood pressure, environmental factors, behavior, etc.

The unified optimal criterion for the maximum entropy spectral analysis was examined with the heart rate of a horse as the model data since we have been thinking of using MEM to extract the common rhythms in all horses. In the model heart rate data, there are many rhythms which had physiological means and therefore we thought that the decided criterions in this experiment can apply to the data of other horses. This chronotropic estimation of heart rate dirunal rhythm, moreover, will be more accurate analysis if results of MEM are reconfirmed by the nonlinear least squares method.

In conclusion, the maximum entropy spectral analysis was able to estimate equine 
heart rate diurnal rhythms with accuracy. It was considered that we could know quantitatively the variations in equine biorhythms, the rhythms affecting performances and the effect of travel [6] by this method. In addition, the equine application of MEM will be expected in the pathologic analysis of cardiovascular diseases, autonomic nervous function, the effect of drugs, etc.

\section{References}

1. Akaike, H. (1970). Statistical predictor identification. Ann. Ins. Statist. Math. 22: 203-217.

2. Aoki, Y. (1987). Numerical Computation by "BASIC". 3rd ed., pp. 93-141, Koronasha, Tokyo (in Japanese).

3. Bottoms, G. D., Roesel, O. F., Rausch, F. D., and Akins, E. L. (1972). Gircadian variation in plasma cortisol and corticosterone in pigs and mares. $\mathrm{Am}$. J. Vet. Res. 33: 785-790.

4. Evans, J. W., Winget, C. M., De Roshia, C., and Holley, D. C. (1976). Ovulation and equine body temperature and heart rate circadian rhythms. $J$. Interdiscipl. Cycle Res. $7:$ 23-37.

5. Hoffsis, G. F., Murdick, P. W., Tharp, V. L., and Adult, K. (1970). Plasma concentration of cortisol and corticosterone in the normal horse. Am.J. Vet. Res. 31: 1379-1387.

6. Houpt. K. A. (1980). Equine biorhythms. Equine Pract. 2: 8-11.

7. Kashiwamura, F. and Shinde, Y. (1990). Time series analysis of cow body temperature measurements obtained via a biological data logger. Jpn. J. Zootech. Sci. 61: 869-875 (in Japanese).
8. Kirkpatrick, J. F., Vaild, R., Devous, S., Scwend, S., Baker, C. B., and Wiesner, L. (1976). Diurnal variation of plasma testosterone in wild stallions. Biol. Reprod. 15: 98-101.

9. Mills, J. N. (1966). Human circadian rhythms. Physiol. Rev. 46: 128-171.

10. Minami, S. (1991). Waveform Data Processing for Scientific Measurement and Instrumentation. 8th ed., pp. 140-180, GQ Shuppan, Tokyo (in Japanese).

11. Ohtomo, N. and Tanaka, Y. (1992). Analysis procedure of the periodic structure of diurnal rhythm in human blood pressure. In: Miyake, H. (ed.), The Structure of Biological Rhythms, 1st ed., pp. 81-102, Fuji Shoin, Sapporo (in Japanese).

12. Otsuka, K., Omori, K., Suzuki, M., and Watanabe, H. (1989). Gircadian variation of blood pressure. Kokyu to Junkan 37: 1045-1054 (in Japanese).

13. Otsuka, K., Sato, T., Saito, H., Kaba, H., Otsuka, K., Seto, K., Ogura, H., and Ozawa, T. (1985). Gircadian rhythm of cardiac bradyarrhythmia episodes in rats. Chronobiologia 12: 11-28.

14. Otsuka, K., Sato, T., Saito, H., Kaba, H., Seto, K., Yanaga, T., Ogura, H., and Ozawa, T. (1985). Role of the suprachiasmatic nuclei of the hypothalamus on diurnal rhythm in cardiac arrhythmias. Heart Vessels 2: 15-22.

15. Otsuka, K., Watanabe, H., and Ogura, H. (1990). Circadian variation of heart rate and heart rhythmicity. Kokyu to Junkan 38: 621-628 (in Japanese).

16. Shimada, S. G. and Marsh, D. J. (1979). Oscillations in mean arterial blood pressure in conscious dogs. Circ. Res. 44: 692-700.

17. Stadler, S. and Deegen, E. (1986). Diurnal variation of dynamic compliance, resistance and viscous work of breathing in normal horses and horses with lung disorders. Equine Vet. J. 18: 171-178.

18. Ulrych, T. J. and Bishop, T. N. (1975). Maximum entropy spectral analysis and autoregressive decomposition. Rev. Geophys. Space Phys. 13: 183-200.

\section{ウマの心拍数日内変動の最大エントロピースペクトル解析基準一山谷吉樹 ${ }^{1}$, 久保勝義 ${ }^{2}$,} 天田明男 ${ }^{2}$, 佐藤 敬 ${ }^{1}{ }^{1}$ 日本大学農獣医学部獣医外科学研究室 $\bar{T} 252$ 神奈川県藤沢市亀 井野1866, ${ }^{2}$ 日本中央競馬会競走馬総合研究所 $=154$ 東京都世田谷区弦巻5-27-7)

ウマの心拍数日内変動の周期変動を推定するため 1 頭のウマを用いて最大エントロピー スペクトル分析の応用を試みた。最大エントロピー法ではその推定の前にサンプリング間 隔および自己回帰モデルの次数（モデル次数）を決めなければならない。そこで，サンプ リング間隔およびモデル次数について検討した。その結果，サンプリング間隔では 5 また は10分毎が，モデル次数は 6 時間より長い周期変動を解析する場合は $\mathrm{N}$ (データ数) $/ 2,1$ から 6 時間周期の変動を解析する場合は N/5 が適当であることがわかった。これらの条件 により検討した結果，このウマの心拍数日内変動には約 1 および $4 ， 5 ， 9 ， 26$ 時間周期の 周期変動が認められた。 